\title{
Reinforcing Effects of Crimped Polypropylene Fibres in High Strength Concrete
}

\author{
Jagan Sivamani, Meyyappan PL
}

\begin{abstract}
Plain cement concrete is strong in compression and weak in tension which fails on application of tensile load. This research focuses on the eradication of such catastrophic failure in plain cement concrete by the utilization of crimped polypropylene fibres in high strength concrete. Experiments involving the addition of fibres in concrete have increased now days for its application in field practices ranging from steel, glass, polyester, polypropylene etc. In our present study, polypropylene fibres were added in the relative volume fractions of $0.1 \%$, $0.2 \%$ and $0.3 \%$ with $w / c$ ratio of 0.35 . Various studies like compressive strength, split tensile strength and flexural strength at the age of 7 days and 28 days under normal curing and steam curing were performed and the behaviour of fibres was studied. Results concluded that addition of crimped fibres at $0.3 \%$ under steam curing had improved the behavioural properties of the concrete.
\end{abstract}

Keywords: Catastrophic, Crimped polypropylene fibres, Normal curing, Steam curing and tension.

\section{INTRODUCTION}

Concrete is a composite material which is strong in compression and weak in tension. To improve the tensile property, reinforcing efficiency of concrete has to be increased which can be done by addition of suitable fibres in concrete. In past research various types of fibres such as steel, glass and polyester fibres have been used in concrete either by volume fractions or weight fractions. Such fibre addition in concrete is one of the effective technologies to improve the tensile properties of concrete. Randomly distributed fibres will have high reinforcing property compared to oriented fibres and improves the strength of the concrete. Failure of the plain cement concrete is sudden and catastrophic and also they posses poor toughness and ductile properties. Various researches have been conducted concluded that addition of polypropylene fibres improved the mechanical properties of the concrete [1-5]. Percentage of addition of polypropylene fibres plays a major role in the improvement of mechanical properties. Study performed by [6] shows the improvement in compressive of concrete by $56.4 \mathrm{MPa}$ at the age of 28 days upon addition of $0.3 \%$ polypropylene fibres. Similar studies upon addition of polypropylene fibres such as $0.5 \%$ to $1 \%$ and up to 3\% improved the mechanical properties of concrete $[7,8$, and 9]. The main objective of the study is to increase the tensile strength of concrete and its reinforcing efficiency. Under such circumstances, the study was performed in examining the behaviour of high strength concrete using polypropylene fibres upon addition by $0.1 \%, 0.2 \%$ and $0.3 \%$ by volumetric fractions. Compressive strength, split tensile

Revised Manuscript Received on December 5, 2019

* Corresponding Author

Jagan Sivamani*, Department of Civil Engineering, Kalasalingam Academy of Research and Education, Krishnankoil, India. Email: s.jagan@klu.ac.in

PL. Meyyappan, Civil department, Kalasalingam Academy of Research and Education, Krishnankoil, India. Email: meyyappan @klu.ac.in strength and flexural strength at the age of 7 days and 28 days were conducted under normal curing and steam curing to study its mechanical properties.

\section{METHODOLOGY}

\section{A. Materials}

OPC of 53 grades, fine aggregate passing through $2.36 \mathrm{~mm}$ sieve confirming to zone II with fineness modulus of 2.7 and specific gravity of 2.67 , coarse aggregates of $10 \mathrm{~mm}$ with specific gravity 2.84 , water confirming to IS $456: 200$ was used. Properties of ingredients used in this study was tested and presented in table I.

Table- I: Properties of Ingredients

\begin{tabular}{|l|l|l|}
\hline S. No & \multicolumn{1}{|c|}{ Properties } & Values \\
\hline 1 & Specific gravity of cement & 3.15 \\
\hline 2 & Specific gravity of fine aggregate & 2.67 \\
\hline 3 & Specific gravity of coarse aggregate & 2.84 \\
\hline 4 & Fineness modulus of fine aggregate & 2.7 \\
\hline 5 & $\begin{array}{l}\text { Fineness modulus of coarse } \\
\text { aggregate }\end{array}$ & 2.95 \\
\hline
\end{tabular}

\section{B. Polypropylene fibres}

Polypropylene fibres collected from the locally available industry near Vellore were used in the study is shown in the Fig.1. Various physical properties of polypropylene fibres are presented in the table II.

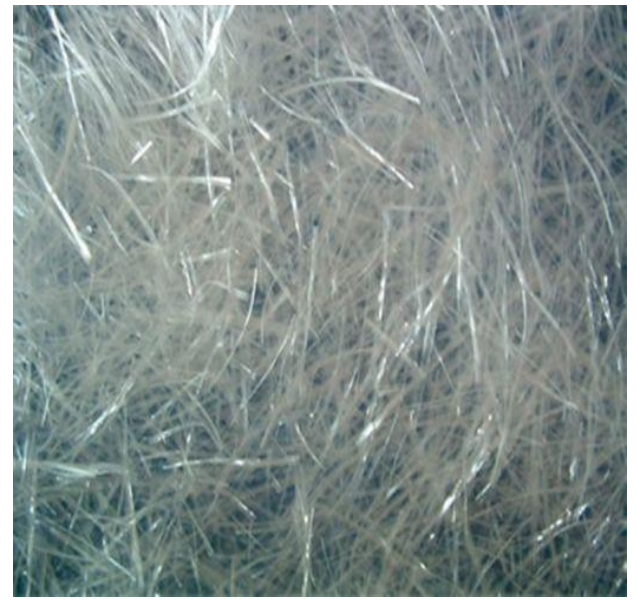

Fig.1.Crimped polypropylene fibres

Table- II: Physical properties of polypropylene fibres

\begin{tabular}{|l|l|l|}
\hline S. No & Properties & Values \\
\hline 1 & Elongation & $40-100 \%$ \\
\hline 2 & Moisture absorption & $0-0.05 \%$ \\
\hline 3 & Relative density & 0.9 \\
\hline
\end{tabular}

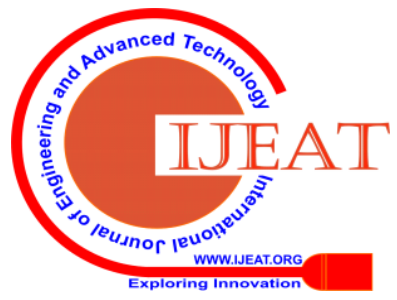




\section{Reinforcing Effects of Crimped Polypropylene Fibres in High Strength Concrete}

\section{Mix Proportions}

Mix proportions were made of M40 grade concrete with w/c ratio of 0.35 . A total of 330 specimens were prepared based on mix combinations to study its mechanical properties. Polypropylene fibres were added at a percentage of $0.1 \%, 0.2 \%$ and $0.3 \%$. Cube moulds of size $150 \mathrm{~mm} \times 150 \mathrm{~mm} \times 150 \mathrm{~mm}$, cylinder moulds of size $150 \mathrm{~mm} \times 300 \mathrm{~mm}$ and prism moulds of size $500 \mathrm{~mm} \times 100 \mathrm{~mm} \times 100 \mathrm{~mm}$ were fabricated to study the mechanical properties. Quantification of mix proportions to prepare concrete specimens is presented in the table III.

Table- III: Mix Proportions

\begin{tabular}{|l|l|}
\hline Grade of concrete & M40 \\
\hline w/c ratio & 0.35 \\
\hline Weight of Cement & $450 \mathrm{Kg} / \mathrm{m}^{3}$ \\
\hline Weight of Fine Aggregate & $623 \mathrm{Kg} / \mathrm{m}^{3}$ \\
\hline Percentage of Polypropylene fibres added & $1085 \mathrm{Kg} / \mathrm{m}^{3}$ \\
\hline
\end{tabular}

\section{Testing of concrete specimens}

Various hardened property tests concrete specimens include compressive strength test on cube specimens (150mmx150mmx150mm), split tensile strength test on cylindrical specimens $(150 \mathrm{mmx} 300 \mathrm{~mm})$ and flexural strength test on prism specimens (500mmx100mmx100mm). All these tests were performed confirming to IS 516:1959 as presented in fig. 2 .
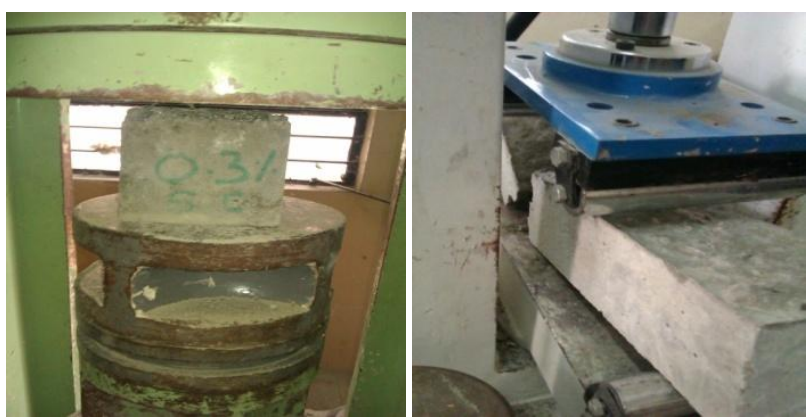

Fig.2.Testing of concrete specimens

\section{RESULTS AND DISCUSSIONS}

\section{A. Effect of fibres on compressive strength}

Compressive strength of concrete with and without polypropylene fibres under all percentages at the age of 7 days and 28 days under normal curing and steam curing is presented in the table IV. From the results it is evident that strength at M3 is found to be $15 \%$ more compared to M0, $11 \%$ more compared to M1 and 3\% more compared to M2 under Normal Curing (NC). On the other hand, when subjected to Steam Curing (SC), the strength of M3 is found to be $3 \%$ more compared to M3 under normal curing. Also strength of M3 under SC is found to be $17 \%$ more compared to M0 under curing and $12 \%$ more compared to M0 under steam curing. This increase in strength is due to the formation of compact structure of concrete with low w/c ratio and tensile property of polypropylene fibres [1-5].
Table- IV: Compressive strength at 7 and 28 days

\begin{tabular}{|c|c|c|c|c|c|}
\hline \multirow{3}{*}{ S.No } & \multirow{3}{*}{ Mix } & \multirow{3}{*}{$\begin{array}{c}\% \text { of } \\
\text { replacement }\end{array}$} & \multicolumn{3}{|c|}{$\begin{array}{c}\text { Compressive strength } \\
(\mathrm{MPa})\end{array}$} \\
\hline & & & \multirow{2}{*}{7 days } & \multicolumn{2}{|c|}{28 days } \\
\hline & & & & $N C$ & $S C$ \\
\hline 1 & M0 & $0 \%$ & 27.82 & 41.16 & 43.5 \\
\hline 2 & M1 & $0.1 \%$ & 29.8 & 42.6 & 45.2 \\
\hline 3 & M2 & $0.2 \%$ & 30.42 & 45.8 & 47.9 \\
\hline 4 & M3 & $0.3 \%$ & 32.3 & 48.2 & 49.3 \\
\hline
\end{tabular}

\section{B. Effect of fibres on split tensile strength}

Various Split tensile strength of concrete with and without polypropylene fibres under all percentages at the age of 7 days and 28 days under normal curing and steam curing is presented in the table V. From the results it is evident that strength at M3 is found to be $15.6 \%$ more compared to M0, $7 \%$ more compared to $\mathrm{M} 1$ and $6.38 \%$ more compared to M2 under Normal Curing (NC). On the other hand, when subjected to Steam Curing (SC), the strength of M3 is found to be $7.5 \%$ more compared to M3 under normal curing. Also strength of M3 under SC is found to be $25 \%$ more compared to M0 under curing and $21 \%$ more compared to M0 under steam curing. This increase in strength is due to the formation of compact structure of concrete with low w/c ratio and tensile property of polypropylene fibres [1-5].

Table- V: Split tensile strength at 7 and 28 days

\begin{tabular}{|c|c|c|c|c|c|}
\hline \multirow{3}{*}{ S.No } & \multirow{3}{*}{ Mix } & \multirow{3}{*}{$\begin{array}{c}\% \text { of } \\
\text { replacement }\end{array}$} & \multicolumn{3}{|c|}{$\begin{array}{l}\text { Split tensile strength } \\
\text { (MPa) }\end{array}$} \\
\hline & & & \multirow{2}{*}{7 days } & \multicolumn{2}{|c|}{28 days } \\
\hline & & & & $N C$ & $S C$ \\
\hline 1 & M0 & $0 \%$ & 1.19 & 1.83 & 1.91 \\
\hline 2 & M1 & $0.1 \%$ & 1.31 & 1.91 & 1.97 \\
\hline 3 & M2 & $0.2 \%$ & 1.32 & 2.08 & 2.15 \\
\hline 4 & M3 & $0.3 \%$ & 1.41 & 2.25 & 2.43 \\
\hline
\end{tabular}

\section{Effect of fibres on flexural strength}

Flexural strength of concrete with and without polypropylene fibres under all percentages at the age of 7 days and 28 days under normal curing and steam curing is presented in the table VI. From the results it is evident that strength at M3 is found to be $15.2 \%$ more compared to M0, $5.9 \%$ more compared to $\mathrm{M} 1$ and $4.7 \%$ more compared to M2 under Normal Curing (NC). On the other hand, when subjected to Steam Curing (SC), the strength of M3 is found to be $10.5 \%$ more compared to M3 under normal curing. Also strength of M3 under SC is found to be $24 \%$ more compared to M0 under curing and $6.6 \%$ more compared to M0 under steam curing. This increase in strength is due to the formation of compact structure of concrete with low w/c ratio and tensile property of polypropylene fibres [1-5]. 
Table- VI: Flexural strength at 7 and 28 days

\begin{tabular}{|c|c|c|c|c|c|}
\hline \multirow{2}{*}{ S.No } & \multirow{2}{*}{ Mix } & \multirow{2}{*}{$\begin{array}{c}\text { \% of } \\
\text { replacement }\end{array}$} & $\mathbf{7}$ days & \multicolumn{3}{|c|}{$\begin{array}{c}\text { Flexural strength } \\
\text { (MPa) }\end{array}$} \\
\cline { 4 - 6 } & & & NC & $S C$ \\
\hline 1 & M0 & $0 \%$ & 2.03 & 4.12 & 5.07 \\
\hline 2 & M1 & $0.1 \%$ & 2.52 & 4.57 & 5.12 \\
\hline 3 & M2 & $0.2 \%$ & 2.65 & 4.63 & 5.20 \\
\hline 4 & M3 & $0.3 \%$ & 2.79 & 4.86 & 5.43 \\
\hline
\end{tabular}

\section{CONCLUSION}

This study presented the effect of polypropylene fibres on mechanical properties upon addition of $0.1 \%, 0.2 \%$, and $0.3 \%$. Upon increase in addition of fibres in concrete, the mechanical property of concrete is found to be increased. Such increase in the mechanical behaviour of concrete is due to the higher tensile behaviour of polypropylene fibres. When fibres are added into, it creates a good bonding with cement matrix thereby increasing the strength of concrete. With respect to curing, it is found that SC specimen's shows better strength compared to NC specimens. Such attribute is due to the acceleration of $\mathrm{C}_{3} \mathrm{~S}$ compound which is responsible high strength of concrete.

\section{REFERENCES}

1. A. Bentur and S. Mindess, "Fibre reinforced cementitious composites" Modern Concrete Technology, Taylor \& Francis, NY, USA, 2006.

2. C. E. Chalioris, "Steel fibrous RC beams subjected to cyclic deformations under predominant shear" Engineering structures., vol. 49, April. 2013, pp. 104-118

3. M. P. Karthik and D. Maruthachalam, "Experimental study on shear behaviour of hybrid fibre reinforced concrete beams" KSCE Journal of Civil Engineering., vol. 19, October. 2015, pp. 259-264.

4. C. E. Chalioris and T. A. Panagiotopoulos, "Flexural analysis of steel fibre reinforced concrete members" Computers and Concrete., vol. 22, Dec. 2018, 10.12989/cac.2018.22.1.011.

5. S. Ahmed, I. A. Bukhari, J. Iqbal, S. Shahzad and A. Qureshi, "A Study on properties of polypropylene fibre reinforced concrete" in $31^{\text {st }}$ conference on our world in concrete and structures, Singapore, 2016, pp. $1-10$.

6. S. Thirumurugan and A. Sivakumar, "Compressive Strength Index of Crimped Polypropylene fibres in High Strength Cementitious Matrix" World Applied Sciences Journal, vol. 24, Mar. 2007, pp. 698-702.

7. G D. Suji, S. C. Natesan and R. Murugesan, "Experimental study on behaviour of polypropylene fibrous concrete beams" Journal of Zhejiang University Science, vol. 8, Aug. 2007, pp. 1101-1109.

8. P.S. Song, S. Hwang and B.C. Sheu, "Strength properties of Nylon and propylene fibre reinforced concretes" Cement and Concrete Research, vol. 35 , Dec. 2005 , pp. 1546-1550.

9. V. M. Sountharrajan, S. Thirumurugan and A. Sivakumar, "Reinforcing Efficiency of Crimped profile of Polypropylene Fibres on the Cementitious matrix" Research Journal of Applied Sciences, Engineering and Technology, vol. 6, Dec. 2013, pp. 2662-2667.

10. IS 10262: 2009, "Indian Standard, recommended guidelines for concrete mix designs", Bureau of Indian Standards.

11. IS 456: 2000, "Indian Standard, Plane and reinforced concrete- Code of practice”, Bureau of Indian Standards.

12. IS 516:1959, "Method of Tests for Strength of concrete", Bureau of Indian Standards.

13. PL. Meyyappan, K.Kumaran, M.Gopalakrishnan and E. Harikrishnan (2018), "Effect of glass fibers, flyash and quarry ash on Strength and Durability Aspects of Concrete - An Experimental Study", IOP Conference Series: Material Science and Engineering, doi:10.1088/1757-899X/396/1/012001.

14. PL. Meyyappan, K.Kumaran, M.Gopalakrishnan and E. Harikrishnan (2018), "Experimental Investigation on the Effect of Silica fume and Pumice stone in Developing Light Weight Concrete", IOP Conference
Series: Material Science and Engineering, doi:10.1088/1757-899X/561/1/012064.

15. PL. Meyyappan, P. Amuthakannan, R. Sutharsan and M. Ahamed Azik Ali (2019), "Utilization of M-Sand \& Basalt Fiber in Concrete: An Experimental Study on Strength and Durability Properties", IOP Conference Series: Material Science and Engineering, doi:10.1088/1757-899X/561/1/012035.

\section{AUTHORS PROFILE}

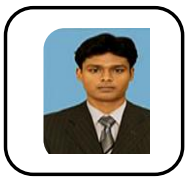

Jagan Sivamani completed M. Tech in Structura Engineering from VIT University in 2015, B.Tech in Civil Engineering from Kongu Engineering College in 2013. I am currently working as Assistant Professor at Kalasalingam Academy of Research and Education. During my career I have published my research worked in 8reputed International Journals and also attended many International conferences, workshops and seminars. Also, a life member of IAENG association.

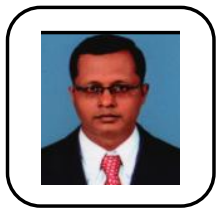

Dr. PL. Meyyappan has completed his graduation and post-graduation from Bharathiyar University and Karunya University respectively. He completed his $\mathrm{PhD}$ from Kalasalingam University. He has 13 years of teaching experience. He has completed 2 sponsored research projects from TNSCST and published more than 25 papers in peer reviewed journals and conferences. He is a life member in ISTE, IEI, IGS, ISET, ISRS. He is serving as Editorial Board Member and Reviewer in various reputed Journals. 